\title{
UNTRADITIONAL SOLUTIONS FOR THE USAGE OF GREENHOUSE EFFECT
}

\author{
V.Zagorska' ${ }^{1}$, A.Āboltiņš̌², A.Upītis ${ }^{3}$
}

1- Latvia University of Agriculture, Institute of Mechanics

J. Čakstes bulv. 5, Jelgava, LV 3001, Latvia

Ph.: +(371)29740492, e-mail: vzagorska@gmail.com

2- Latvia University of Agriculture, Institute of Mechanics

J. Čakstes bulv. 5, Jelgava, LV 3001, Latvia

3- Latvia University of Agriculture, Research Institute of Agricultural Machinery

1 Instituta St, Ulbroka, Riga region, LV 29310, Latvia

\begin{abstract}
The heat solar energy traditionally is used in greenhouses for ensuring optimal plant vegetation regime in our climatic conditions. Glass verandas built during last centuries at the south side of living houses and summer cottages are appreciated as original use of solar energy. Veranda as light and warm room was used for different household needs and also for social activities.

Up-to-date materials and technologies proposes wide spectrum of innovative activities for greenhouses and conservatories. The variable amount of solar energy is possible to smooth out by using accumulation system. In the paper results from vegetable drying experiments are presented. In the research used products - carrots, dry matter of the product at the start $8.5 \%$, chopped product-9.9\%, after desiccation - equilibrium moisture content $10-11 \%$. The experimental device placed in the room is simulating the processes, which would occur if we use greenhouse for product drying, accordingly making changes in the design of conventional greenhouses by separating drying section from growing section, supplying warm heated in the greenhouse upper layer air from the bottom by forcing it with axial ventilator, and accordingly choosing appropriate accumulation system for energy storage in case when outside air temperature drop occurs.
\end{abstract}

Keywords: greenhouses, heat energy accumulation, drying.

\section{Introduction}

The heat solar energy traditionally is used in greenhouses for ensuring optimal plant vegetation regime in our climatic conditions. Glass verandas built during last centuries at the south side of living houses and summer cottages are appreciated as original use of solar energy. Veranda as light and warm room was used for different household needs and also for social activities $[1,2]$.

Up-to-date greenhouses are equipped with effective ventilation, extra lightning and heating systems, what ensure optimal plant vegetation regimes and extend greenhouses' life time, but simultaneously using big amount of energy sources. As interest of dried products is rising, the new energy effective technologies for product drying are looked for. Nowadays drying processes are characterized with high intensity, but also with high energy consumption and low energy efficiency $[3,4,5]$.

By analogy of the nature processes, for example seed drying in variable environment conditions, possibilities of the drying of biological products in variable temperature conditions are being evaluated.

Great increase of the volume of biological agriculture production - mainly in small farms, conservation of biologically high value production with minimal drying processes expenses and usage of local energy sources at the moment attracts increasing interest [6].

In south countries solar heat has been used for a long time for different product drying. It is easier and more convenient to keep dried products comparing to preserved products [1]. 
The aim of our research is to evaluate efficiency of desiccation processes in greenhouses made from modern materials with minimal changes in ventilation and heating systems, minimizing heat losses and equalizing variable solar heat flow applying heat accumulation system

\section{Materials and methods}

If we want to use solar energy stored in the greenhouse, we need to know the temper of the solar radiance. In the Table 1 the amount of energy gained from the solar collector is presented, the data is taken from the Ulbroka Research Institute of Agricultural Machinery solar collector experiments. It is seen that, it is possible to use the solar collector from April to September because of the amount of gained energy $53.3-89.3 \mathrm{kWh} \mathrm{m}^{-2}$, speaking about green houses, the similar situation occurs - during April to October it is possible to dry products in the greenhouse without additional energy use, but if we want to dry products during the rest season, then it is needed to provide additional energy amount, for example by burning biomass.

Amount of energy gained from solar collector $\mathrm{kWh} \mathrm{m}^{-2}$,

Table 1. coefficient of performance $\mathbf{4 4 . 3 \%}$

\begin{tabular}{|l|l|}
\hline Month & $\begin{array}{l}\text { Amount of energy gained from solar } \\
\text { collector } \mathbf{~} \mathbf{W h} \mathbf{~ m}^{-2}\end{array}$ \\
\hline March & 42.8 \\
\hline April & 55.8 \\
\hline May & 71.7 \\
\hline June & 89.3 \\
\hline July & 88.5 \\
\hline August & 71.2 \\
\hline September & 53.3 \\
\hline October & 25.5 \\
\hline Total & $\mathbf{4 9 8 . 1}$ \\
\hline
\end{tabular}

Speaking about heat energy variations during the 24 hour cycle, in Figure 1 it is very well seen, that temperature is the highest from $11.30 \mathrm{am}$ to $3 \mathrm{pm}$, at the same time air humidity is the lowest. It is very important to add, that the highest humidity level is from 4am to 6am. Speaking about drying process, the $90 \%$ humidity level during morning time will influence the overall humidity level in the greenhouse, for this reason it is advisable to stop the drying process, id est to stop the ventilation processes during night time. 


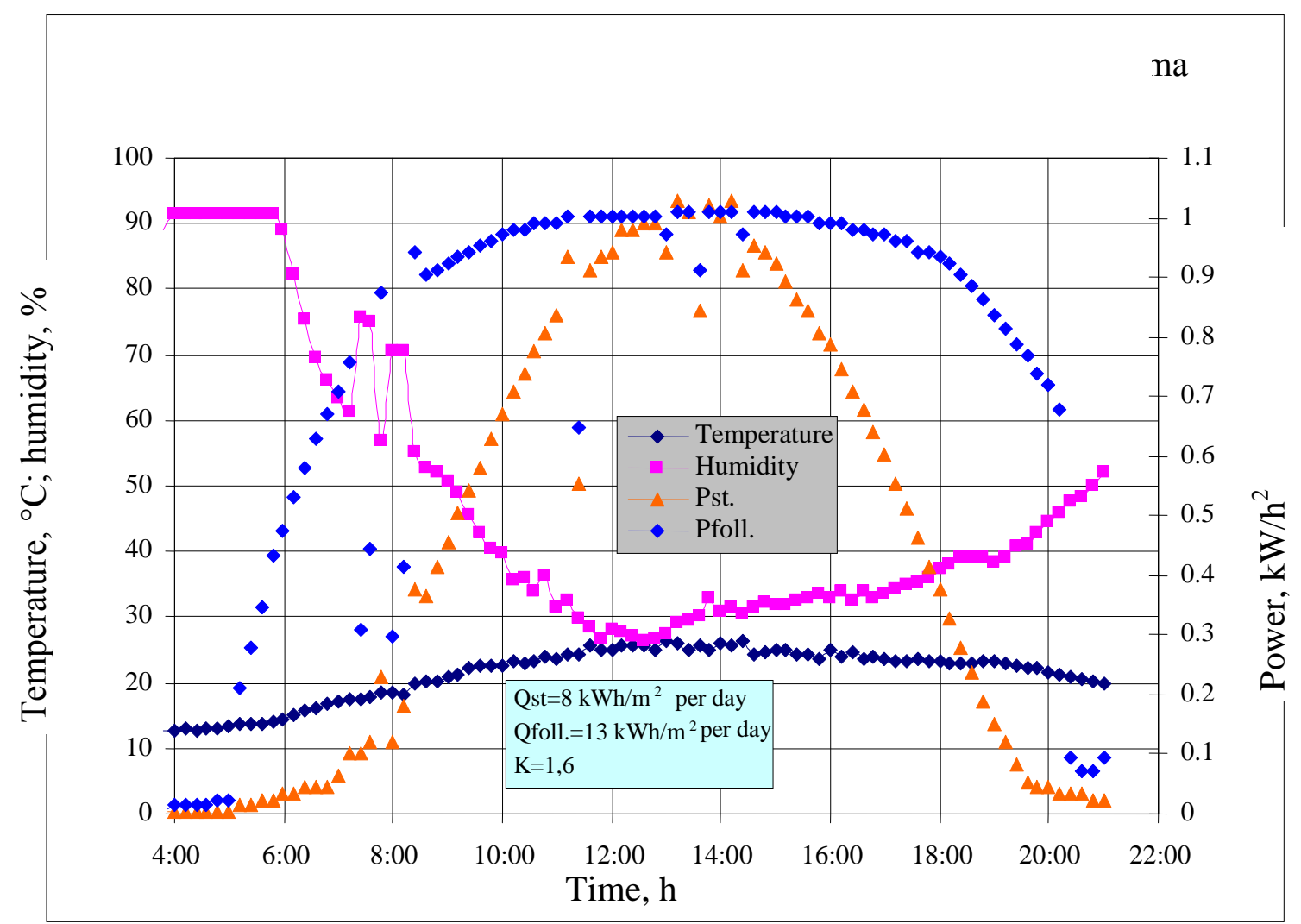

Fig. 1. With MD-4 registered air temperature, humidity and Solar radiation power of two different solar collectors - stationary and following; Ulbroka $30^{\text {th }}$ June 2006

Speaking about possibilities to accumulate the heat energy, it is necessary to mention, that there are many different ways of energy accumulation. It is possible to accumulate heat energy by solid or liquid matter, using different materials. In the table below, some examples of heat accumulation are presented.

Table 2.

Characteristics of the HAS

\begin{tabular}{lllll}
\hline Character of HAS & $\begin{array}{l}\text { Stone } \\
\text { chip }\end{array}$ & Water & $\begin{array}{l}\text { Sodium } \\
\text { sulphate }\end{array}$ & Paraffin \\
\hline $\begin{array}{l}\text { HAS mass for accumulation of 1 GJ heat } \\
\text { energy at } \Delta \mathrm{T}=20^{\circ} \mathrm{C}, \mathrm{kg}\end{array}$ & 60000 & 11900 & 3300 & 3750 \\
\hline $\begin{array}{l}\mathrm{HAS} \text { mass as the ratio to water mass, } \\
\mathrm{kg} / \mathrm{kg}\end{array}$ & 5 & 1 & 0.28 & 0.32 \\
\hline $\begin{array}{l}\mathrm{HAS} \text { volume for accumulation of 1 GJ } \\
\text { heat energy at } \Delta \mathrm{T}=20^{\circ} \mathrm{C}, \mathrm{m}^{3}\end{array}$ & 49.6 & 11.9 & 2.26 & 4.77 \\
\hline $\begin{array}{l}\mathrm{HAS} \text { volume } \text { as the ratio to water } \\
\text { volume } \mathrm{m}^{3} / \mathrm{m}^{3}\end{array}$ & 4.2 & 1 & 0.19 & 0.4 \\
\hline
\end{tabular}



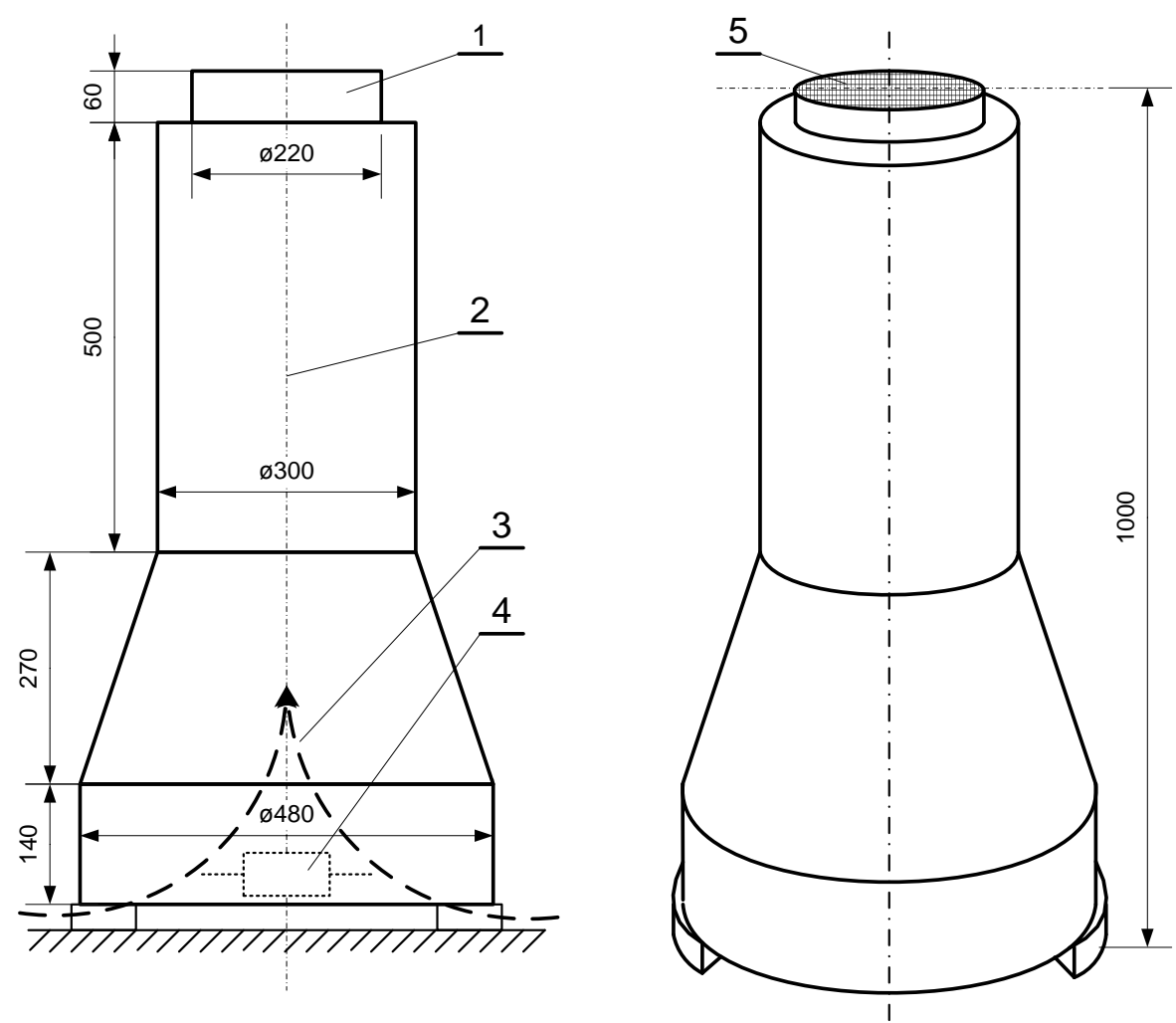

Fig. 2. The scheme of the experimental device

1 - outflow air temperature; 2 - inflow air temperature; 3 -inflow air; 4 - heating element; 5 - bolter with product

In Figure 2 the scheme of equipment used in our desiccation experiments is shown. The diameter of the bolter 5 is $20 \mathrm{~cm}$, area of the bolt $0.031 \mathrm{~m}^{2}$. This device was used for determination of changes in mass of different products at minimal air flow at temperature $36-$ $38^{\circ} \mathrm{C}$ (convectional heat flow due to warm air rise to the top) in device, comparing with results of drying process in the room at the same surrounding air temperature $36-38^{\circ} \mathrm{C}$. The experimental device placed in the room is simulating the processes, which would occur if we use greenhouse for product drying, accordingly making changes in the design of conventional greenhouses by separating drying section from growing section, supplying warm heated in the greenhouse upper layer air from the bottom by forcing it with axial ventilator, and accordingly choosing appropriate accumulation system for energy storage in case when outside air temperature drop occurs.

In the research used products - carrots, dry matter of the product at the start $8.5 \%$, chopped product $-9.9 \%$, after desiccation - equilibrium moisture content $10-11 \%$.

The product was chopped before drying, the thickness chips was 1-2 $\mathrm{mm}$, the length 15-2025-30 mm, the width 4-5 mm, the thickness of layer $25-30 \mathrm{~mm}$, at periodical 20-24 h cycle at air temperature $36-38^{\circ} \mathrm{C}$ and surrounding air temperature $14-15^{\circ} \mathrm{C}$. The balance of the product was as follows: at the start $200 \mathrm{~g}$ of product was taken, and at the end $25 \mathrm{~g}$ left, that means - the mass of separated water was $175 \mathrm{~g}$. 


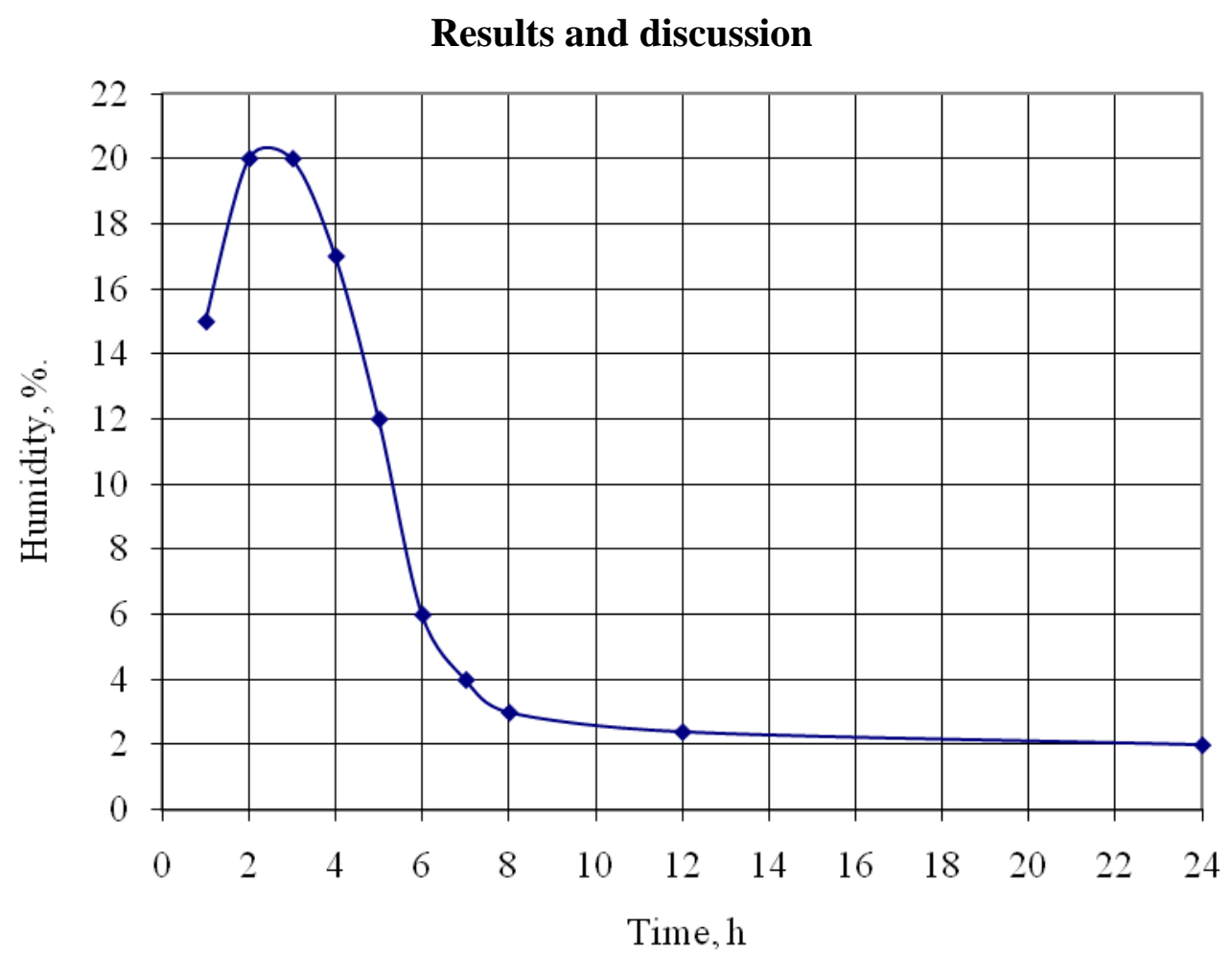

Fig. 3. The mass changes of the drying product during 24 hour drying cycle with convectional air flow

In Figure 3 results from drying process in the experimental device are shown. As it is seen 70 to $75 \%$ of water is separated during the first $3-4$ hours drying period. The intensive drying process is because of convection air flow, which occurs due to warm air rise to the top.

In Table 3 changes of product mass changes are shown, when in the room there is no air flow and surrounding air temperature is $36-38^{\circ} \mathrm{C}$. Comparing results from different drying process (Figure 3 and Table 3), it is seen that higher intensity is achieved during drying process at intensive air flow. Analyzing experimental data of the drying process without air flow it is seen, that in this case process goes on more softly, during first 4 hours equal amount of moisture is drained.

Table 3.

The mass changes of the drying product during $\mathbf{2 4}$ hour drying cycle with intensive air flow

\begin{tabular}{|l|l|}
\hline Time period, $\mathrm{h}$ & Humidity, $\%$ \\
\hline $0-1$ & 6 \\
\hline 3 & 6 \\
\hline 3 & 6 \\
\hline 4 & 6 \\
\hline 5 & 3 \\
\hline-24 & 72 \\
\hline
\end{tabular}




\section{Conclusions}

1. During periodical drying process in greenhouses at the temperature $36-38^{\circ} \mathrm{C}$ and cycle duration 20-24 hours it is possible to get the product with humidity level 10-12\%.

2. Small and average area greenhouses are possible to transform to space for different product drying processes at a quite low expenses.

3. Currently available new generation Solar collectors, water accumulation tanks, heat pumps, water heating boilers with costs for about 3.5 to 5 thousands Ls, comparing with small and average size greenhouse expenses from 1 to 2 thousands.

4. More simple and available heat accumulation method at the moment is greenhouse, were solid stone material is used for greenhouse basement were air flow channels are implemented using low energy consuming fans.

\section{Acknowledgment}

Research is completed by financial support of European Structural Fund: Attraction of human resources for investigation of renewable energy resources. Realized by the Project Department of Latvia University of Agriculture (contract no. 2009/0225/1DP/ 1.1.1.2.0/09/APIA/VIAA/129).

\section{References}

1. Харченко Н.В. , Индивидуальные солнечные установки, 1991., Москва, Энергоатомиздат, с. 208

2. Abolins J., Ernests J. Heat energy in manufacturing and households. 1986. Rīga:’Zinātne”, pp 123. (in Latvian)

3. How does energy occur? 2010. Available at: www.zalaenergija.lv (in Latvian)

4. Greenhouse prices. 2010. Available at: http://www.hothouses.lv/ceni.php (in Latvian)

5. Warm air generator. 2010. Available at: http://www.grandeg.lv/?1=3\&item_id=162 (in Latvian)

6. Upītis A., Kristapsons M., Ziemelis I., Šķēle A. Local energy sources in energy supply system of agricultural district. 2009. In: proceedings of 8 th International Scientific Conference "Engineering for Rural Development”. May 28-29. 2009. Jelgava. Latvia, p.361-364. 